\title{
$p, p^{\prime}$-Dichlorodiphenyldichloroethylene Induces Colorectal Adenocarcinoma Cell Proliferation through Oxidative Stress
}

\author{
Li Song ${ }^{1,2}$, Jianxin Liu ${ }^{1}$, Xiaoting Jin ${ }^{1}$, Zhuoyu $\mathrm{Li}^{1,3 *}$, Meirong Zhao ${ }^{4}$, Weiping Liu ${ }^{2 *}$ \\ 1 Institute of Biotechnology, Key Laboratory of Chemical Biology and Molecular Engineering of National Ministry of Education, Shanxi University, Taiyuan, China, 2 MOE \\ Key Lab of Environmental Remediation and Ecosystem Health, College of Environmental and Resource Sciences, Zhejiang University, Hangzhou, China, $\mathbf{3}$ College of Life \\ Science, Zhejiang Chinese Medical University, Hangzhou, China, 4 Research Center of Environmental Science, Zhejiang University of Technology, Hangzhou, China
}

\begin{abstract}
$p, p^{\prime}$-Dichlorodiphenyldichloroethylene (DDE), the major metabolite of Dichlorodiphenyltrichloroethane (DDT), is an organochlorine pollutant and associated with cancer progression. The present study investigated the possible effects of $p, p^{\prime}$-DDE on colorectal cancer and the involved molecular mechanism. The results indicated that exposure to low concentrations of $p, p^{\prime}$-DDE from $10^{-10}$ to $10^{-7} \mathrm{M}$ for $96 \mathrm{~h}$ markedly enhanced proliferations of human colorectal adenocarcinoma cell lines. Moreover, $p, p^{\prime}$-DDE exposure could activate $W n t / \beta$-catenin and Hedgehog/Gli1 signaling cascades, and the expression level of c-Myc and cyclin D1 was significantly increased. Consistently, $p, p^{\prime}$-DDE-induced cell proliferation along with upregulated c-Myc and cyclin D1 were impeded by $\beta$-catenin siRNA or Gli1 siRNA. In addition, $p, p^{\prime}-$ DDE was able to activate NADPH oxidase, generate reactive oxygen species (ROS) and reduce GSH content, superoxide dismutase (SOD) and calatase (CAT) activities. Treatment with antioxidants prevented $p, p^{\prime}$-DDE-induced cell proliferation and signaling pathways of Wnt/ $\beta$-catenin and Hedgehog/Gli1. These results indicated that $p, p^{\prime}$-DDE promoted colorectal cancer cell proliferation through Wnt/ $\beta$-catenin and Hedgehog/Gli1 signalings mediated by oxidative stress. The finding suggests an association between $p, p^{\prime}$-DDE exposure and the risk of colorectal cancer progression.
\end{abstract}

Citation: Song L, Liu J, Jin X, Li Z, Zhao M, et al. (2014) p, p'-Dichlorodiphenyldichloroethylene Induces Colorectal Adenocarcinoma Cell Proliferation through Oxidative Stress. PLoS ONE 9(11): e112700. doi:10.1371/journal.pone.0112700

Editor: Chunming Liu, University of Kentucky, United States of America

Received July 22, 2014; Accepted October 10, 2014; Published November 11, 2014

Copyright: (c) 2014 Song et al. This is an open-access article distributed under the terms of the Creative Commons Attribution License, which permits unrestricted use, distribution, and reproduction in any medium, provided the original author and source are credited.

Data Availability: The authors confirm that all data underlying the findings are fully available without restriction. All relevant data are within the paper and its Supporting Information files.

Funding: This work was supported by the National Natural Sciences Foundation of China (No. 31271516, No. 21207084), Research Fund for the Doctoral Program of Higher Education of China (20111401110011), China Postdoctoral Science Foundation (2012M521178) and Natural Sciences Foundation of Shanxi (20140110275). The funders had no role in study design, data collection and analysis, decision to publish, or preparation of the manuscript.

Competing Interests: The authors have declared that no competing interests exist.

* Email: Izy@sxu.edu.cn (ZL); Wliu@zju.edu.cn (WL)

\section{Introduction}

Dichlorodiphenyltrichloroethane (DDT) was the most used organochlorine pesticide in the world. DDT became banned in the 1970s in most western countries because of its adverse effects on wildlife. DDT is still being used to prevent malaria and typhoid in some developing countries [1,2]. Although DDT has generally been restricted for use over decades, the metabolites exposure still exists mainly through metabolic conversion in the body. $p, p$ 'Dichlorodiphenyldichloroethylene ( $p, p$ '-DDE) is DDT's major metabolite with high persistence and lipophilicity. High $p$, $p$ '-DDE levels are usually found in human blood and tissues [3-6]. Accumulated evidences indicate that $p$, $p$ '-DDE exposure is related to repercussions in human health, such as neurotoxicity, immunotoxicity and cancinogenesis. [7-13]. Thus, investigations involved in adverse effects of $p, p$-DDE on human health, especially its link with cancer, are receiving more and more attentions.

Colorectal cancer (CRC) is the third most commonly diagnosed cancer and the second leading cause of cancer death in the United States [14]. The GRC incidence is related to multiple risk factors including hereditary factor, lifestyle and body mass [15-17]. It is noteworthy that chemical contamination of food is also considered as an potential factor, which has increased the concerns of the public health [18-24].

Epidemiological investigations have suggested an association between $p, p$ '-DDE exposure and CRC. Higher serum $p$, $p$ '-DDE levels were found in CRC patients from Egypt $[19,20]$. In China, CRC incidence was significantly related to residual $p, p$-DDE in rice [18]. Howsam et al discovered that the role of $p, p$ '-DDE in CRG risk may be more complex [24]. The association between $p, p$ '-DDE exposure and CRC was not remarkable for entire population of cases, but they were significant for the subset of tumors with mutation of $p 53$ gene or wild-type K-ras [24]. Although epidemiological data suggested $p, p$-DDE exposure may improving CRG incidence, the molecular mechanism underlying its promoting effects on CRG remains unclear.

Aberrant cell signaling pathways play vital roles in most CRCs progression. Both Wnt/ $\beta$-catenin and Hedgehog/Glil signaling pathways were highly implicated in CRC development [25-28]. In the presence of Wnt signaling, $\beta$-catenin is released from a destruction complex including Axin, tumor suppressors adenomatous polyposis (APG), glycogen synthase kinase-3 $\beta$ (GSK3 $\beta$ ) and casein kinase $1 \alpha(\mathrm{CK} 1 \alpha)$. $\beta$-catenin becomes stable in cytoplasm 
and then transported into cell nucleus to regulate target genes transcription [29]. When Hedgehog/Glil pathway is activated, the binding of Hh ligand to PTCH1 protein relieves the SMO signal transducer from Patched-dependent suppression. Glil is accumulated in the nuclear, and leads to Glil-dependent transcriptional activation of targets genes [30-32]. Activation of both Wnt/ $\beta$-catenin and Hedgehog/Glil signaling pathways results in the over-expression of cancer-related genes such as cyclin $D$ and $M y c$, which are involved in cancer development $[29,32,33]$.

It has been known that $p, p$-DDE could induce the generation of reactive oxygen species (ROS) such as superoxide $\left(\mathrm{O}_{2}{ }^{-}\right)$and hydroxyl radical $\left(\mathrm{OH}^{-}\right)$. Shi et al. [34] showed $p, p$-DDE induced apoptosis of rat sertoli cells by ROS dependent activation of NF$\kappa \mathrm{B}$ and FasL-dependent pathways. Oxidative stress plays critical role in inducing CRC progression. Some carcinogens such as arsenic and chromium promote CRG development via ROSmediated pathways $[35,36]$. Our previous study demonstrated that $p, p$-DDT, precursor of $p, p^{\prime}$-DDE induced colorectal cancer growth through oxidative stress-mediated pathways [37]. Therefore, it is likely that $p, p$ '-DDE promotes CRC by oxidative stressmediated signaling pathways.

The aim of the present study is to investigate the effects of low concentrations of $p, p$ '-DDE on colorectal cancer and the involved mechanism concerning oxidative stress and two critical CRCrelated pathways, Wnt/ $\beta$-catenin and Hedgehog/Glil signalings. The results demonstrated that $p, p$-DDE exposure promoted colorectal adenocarcinoma cell proliferation through activated Wnt/ $\beta$-catenin and Hedgehog/Glil signalings, which were mediated by oxidative stress.

\section{Materials and Methods}

\section{Chemicals and reagents}

$p$, $p$-Dichlorodiphenyldichloroethylene ( $p, p$ '-DDE) was from Bestown (Beijing, China) and was dissolved in dimethyl sulfoxide (DMSO, Sigma) to get the stock concentration of $100 \mathrm{mM}$ for the in vitro assays. 3-(4, 5-dimethylthiazol-2-yl)-2, 5-diphenyl tetrazolium bromide (MTT), superoxide dismutase (SOD) and catalase (CAT) were purchased from Sigma (St. Louis, MO, USA). $N$ Acetyl-L-cysteine (NAC), 2', 7'-dichlorofluorescein diacetate (DCFH-DA), cytoplasmic and nuclear protein extraction kit,
BCA protein kit and western lysis buffer were from Beyotime Institute of Biotechnology (Nan tong, China). RPMI 1640 medium, Dulbecco's modified Eagle medium (DMEM) and fetal bovine serum were from Gibco BRL (Grand Island, NY, USA). Assay kits for superoxide dismutase (SOD), glutathione (GSH) and catalase (CAT) were provided by the Nanjing Jiancheng Corp (China). Enhanced chemiluminescence kit was from Peirce (Tottenhall, UK). Trizol reagent, PrimeScript RT Master Mix and the SYBR green-based RT-PCR kit were from Takara Biotechnology (Japanese). Antibody to GSK $3 \beta$ and phosphoGSK $3 \beta$ (Ser9) were obtained from Cell Signaling (Beverly, MA, USA). Antibody to $\beta$-catenin and PGNA were obtained from Abmart (USA). Antibody to phospho- $\beta$-catenin (Ser33) was from BBI (UK). Antibodies to c-Myc, Lamin B1 and cyclin D1 were purchased from Bioword (USA). Antibody to $\alpha$-tubulin was a gift from Professor Inke S. Nathke (University of Dundee, UK). Antibody to Glil was purchased from Santa Cruz (Heidelberg, Germany). Horseradish peroxidase (HRP)-linked anti-rabbit IgG, anti-mouse IgG, anti-rat IgG and Lipofectamine 2000 were purchased from Invitrogen (USA). Non-silencing small interference RNA (siRNA), $\beta$-catenin-siRNA and Glil-siRNA were synthesized by Genepharma Company (Shanghai, China).

\section{Cell culture and treatment}

Human colorectal adenocarcinoma DLD1 and SW620 cells were purchased from the Institute of Cell Research (Shanghai, China) and cultured as described previously [37,38]. To observation of $p, p$-DDE cytotoxicity, cells were exposed to various concentrations of $p, p$-DDE (from $10^{-12}$ to $10^{-4} \mathrm{M}$ ) for $96 \mathrm{~h}$. Control group was $0.1 \%(\mathrm{v} / \mathrm{v})$ DMSO in medium. To detect the effect of $\beta$-catenin or Glil silence on $p, p$-DDE-induced DLD1 cell proliferation, cells were transfected with $\beta$-catenin, Glil siRNA or non-silencing siRNA, followed by incubating in medium containing $10^{-9} \mathrm{M}$ of $p, p$ '-DDE or the same amount of DMSO as the working solution. To determine the effects of NAC, SOD or CAT on $p, p$-DDE-induced colorectal adenocarcinoma cell proliferation, cells were exposed to $10^{-9} \mathrm{M}$ of $p, p$-DDE alone or coexposed with NAC $\left(10^{-3} \mathrm{M}\right)$, SOD $(100 \mathrm{U} / \mathrm{ml})$ or CAT (500 U/ $\mathrm{ml}$ ) for $96 \mathrm{~h}$. The equal amount of DMSO was added to medium for control cells.
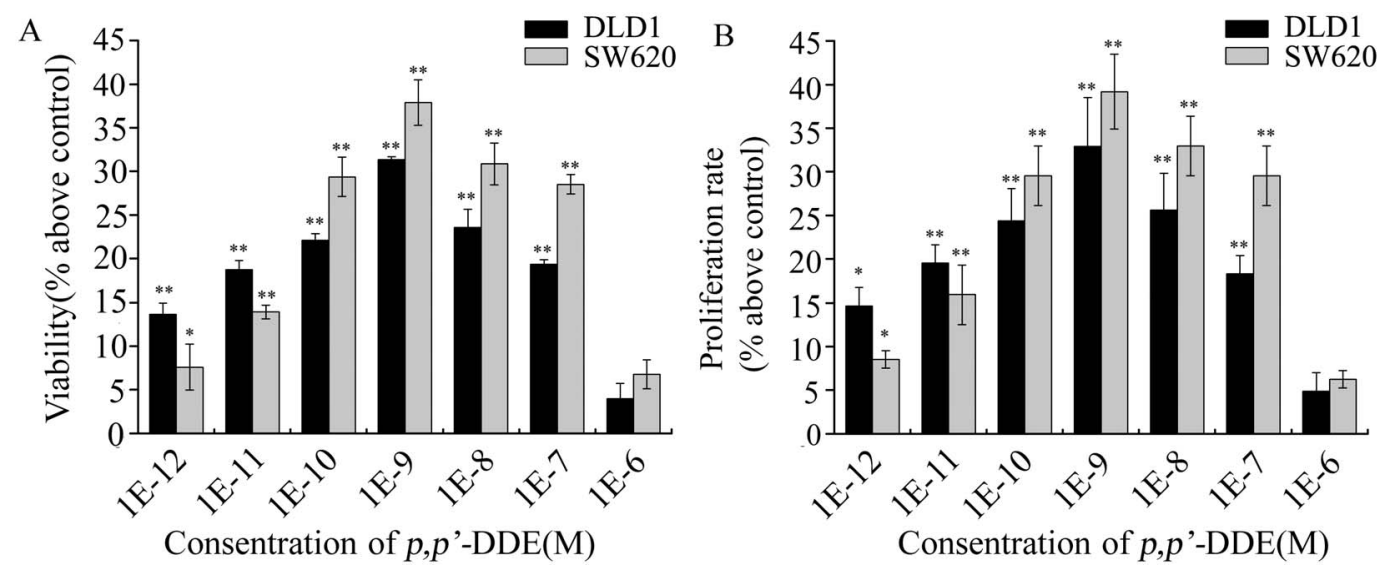

Figure 1. Low concentrations of $p, p^{\prime}$-DDE promote colorectal adenocarcinoma cell proliferation. After DLD1 or SW620 cells were exposed to $10^{-12}$ to $10^{-6} \mathrm{M} p, p^{\prime}$-DDE for $96 \mathrm{~h}$, cell viability $(\mathrm{A})$ and proliferation rate (B) were determined using MTT and cell number assays, respectively. Values are percent changes above the control (DMSO, $0.1 \%$ ) as the mean \pm SD of three independent experiments. ${ }^{*} p<0.05$ and ${ }^{* *} p<$ 0.01 compared to control cells.

doi:10.1371/journal.pone.0112700.g001 
A

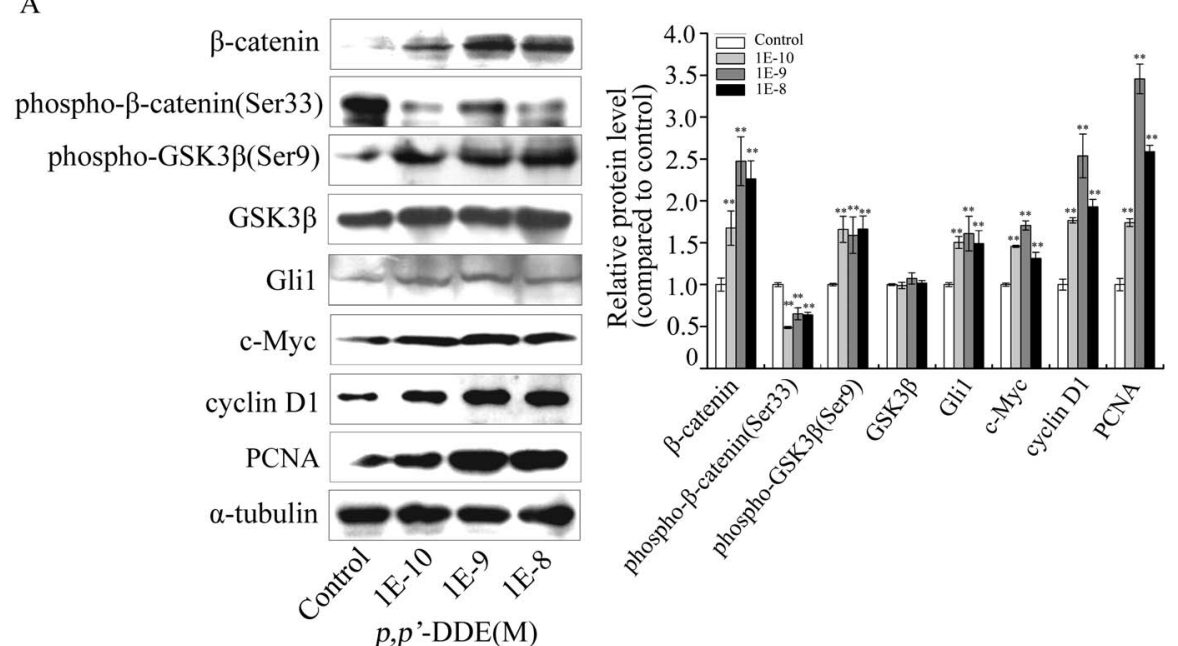

$\mathrm{B}$

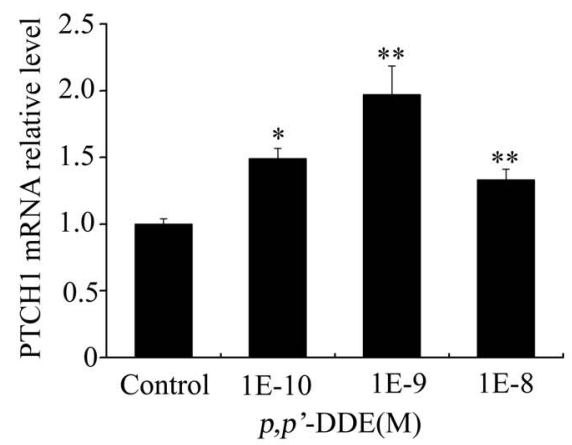

C
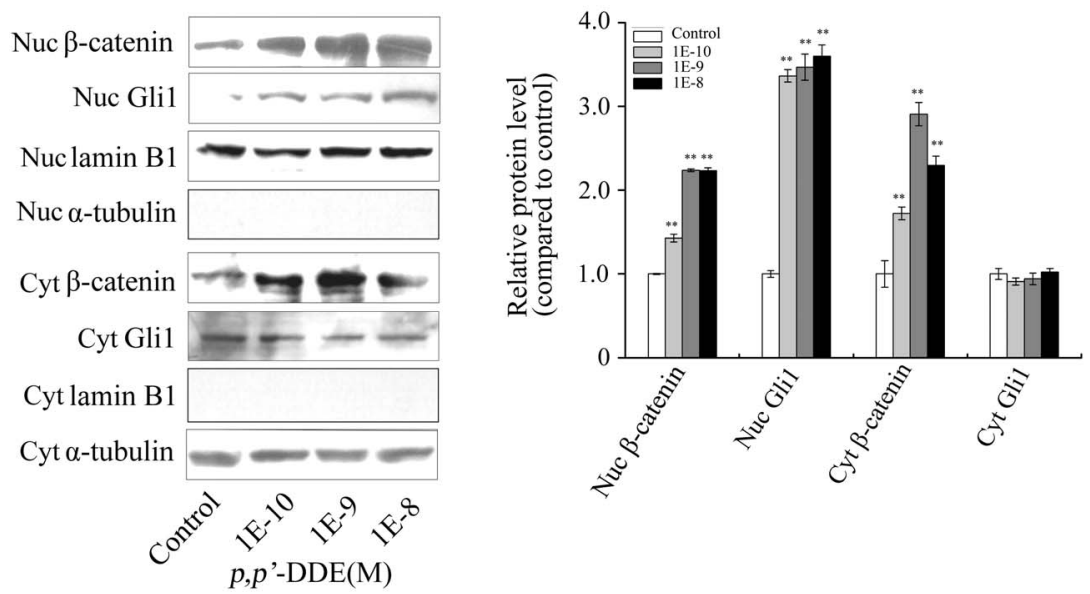

Figure 2. $p, p^{\prime}$-DDE upregulates Wnt/ק-catenin and Hedgehog/Gli1 signalings in DLD1 cells. After DLD1 cells were treated with $p, p^{\prime}$-DDE $\left(10^{-10}, 10^{-9}, 10^{-8} \mathrm{M}\right)$ for $96 \mathrm{~h}$, (A) the protein levels of $\beta$-catenin, phospho- $\beta$-catenin (Ser33), phospho-GSK3 $\beta$ (Ser9), GSK3 $\beta$, Gli1, c-Myc, cyclin D1 and PCNA were examined by western blotting. $\alpha$-tubulin was used as the loading control; Grayscale scan analysis of western blot bands from three independent experiments were shown in right panel of graph. ${ }^{* *} p<0.01$ compared to control cells. (B) mRNA expression of PTCH1 was quantified by quantitative real-time PCR analysis. Relative mRNA levels were normalized with control mRNA. The data were acquired from three biologically independent experiments. Value shown was given as the \pm SD. ${ }^{*} p<0.05$ and ${ }^{* *} p<0.01$ compared to control. (C) Western blotting was performed to analyze the amounts of cytoplasmic or nuclear $\beta$-catenin and Gli1 proteins. $\alpha$-tubulin or lamin B1 was used as a control. Grayscale scan analysis of western blot bands from three independent experiments were shown in right panel of graph. ${ }^{* *} p<0.01$ compared to control cells. doi:10.1371/journal.pone.0112700.g002

\section{Cell viability assay and cell counts}

Cell viability was determined by MTT assay. Cells were seeded in 96-well plates $\left(10^{3}\right.$ cells per well). After treatment with $p$, $p$ '-DDE for $96 \mathrm{~h}$, cells were incubated in culture medium containing MTT $\left(0.5 \mathrm{mg} \mathrm{ml} \mathrm{m}^{-1}\right)$ for $4 \mathrm{~h}$ at $37^{\circ} \mathrm{C}$. The medium was replaced by
DMSO and the absorbance at $570 \mathrm{~nm}$ was measured using a microplate reader. Cell viability $(\%)$ was defined relative to untreated control and calculated based on the following formula: Viability $(\%$ above control $)=\left(\mathrm{A}_{570}\right.$ of treated cells $-\mathrm{A}_{570}$ of control $) / A_{570}$ of control $\times 100$. Meanwhile, cells were seeded in 12- 
A

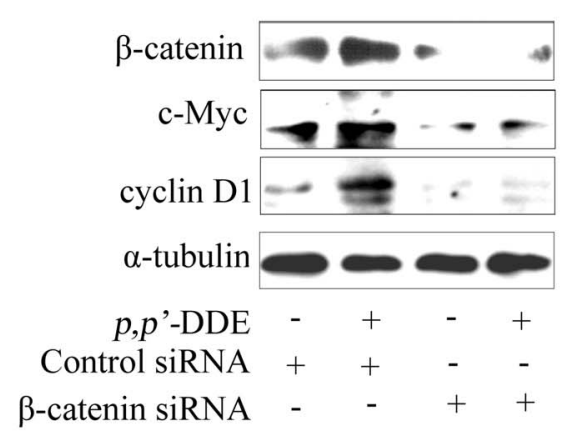

B

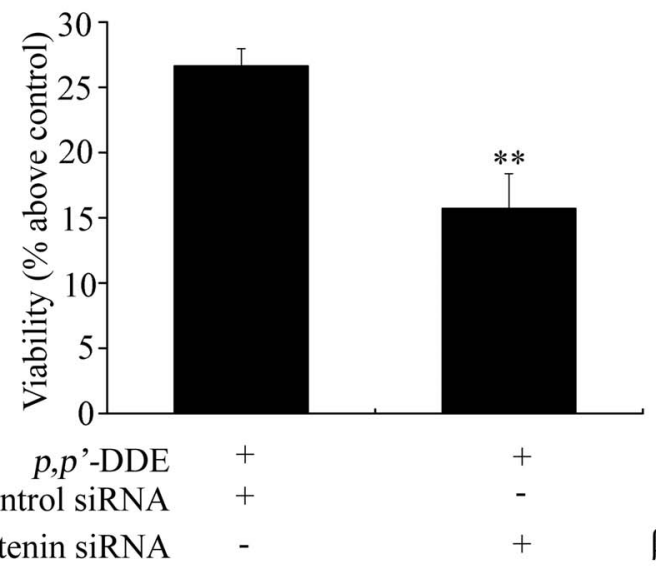

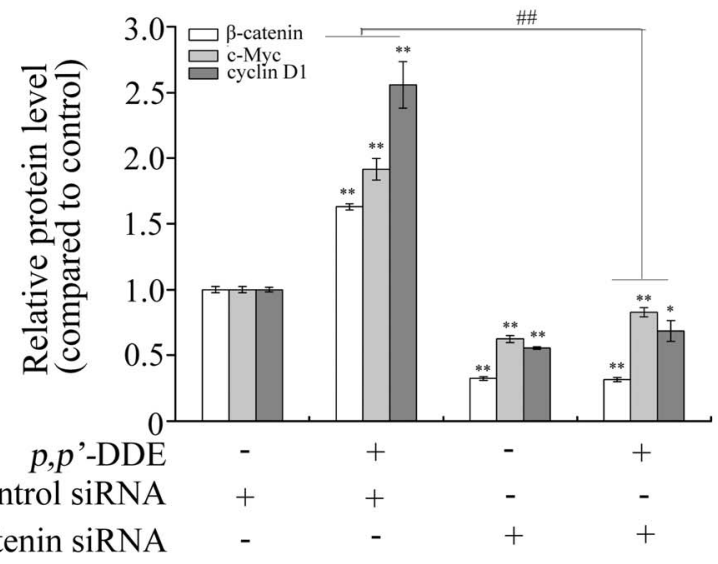

$\mathrm{C}$

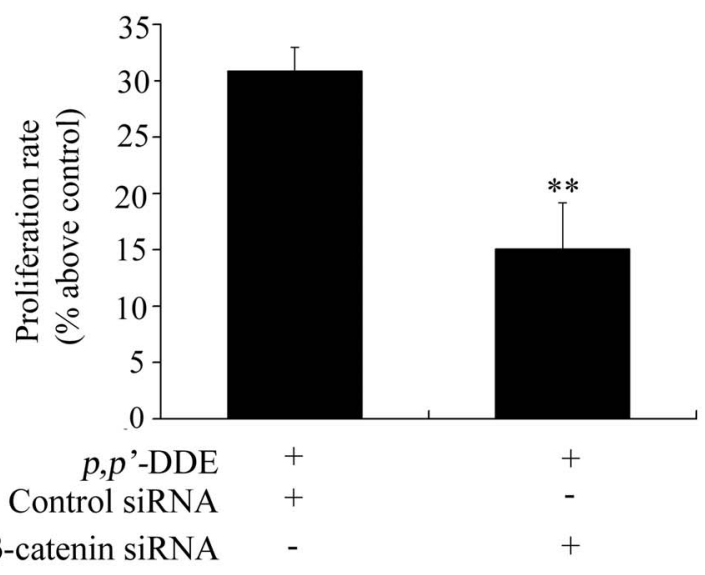

Figure 3. Inhibition of $\mathbf{W n t} / \boldsymbol{\beta}$-catenin signaling blocks $\boldsymbol{p}, \boldsymbol{p}$-DDE-induced DLD1 cell proliferation. After DLD1 cells were transfected with control siRNA or $\beta$-catenin siRNA, followed by treating with $p, p^{\prime}$-DDE $\left(10^{-9} \mathrm{M}\right)$ for $96 \mathrm{~h},(\mathrm{~A})$ western blotting was performed to analyze $\beta$-catenin, $\mathrm{c}$ Myc and cyclin D1. $\alpha$-tubulin was used as a control; Images are representative of three independent experiments that showed similar results. Grayscale scan analysis of western blot bands were shown in right panel of graph. ${ }^{*} p<0.05$ and ${ }^{* *} p<0.01$ compared to the cells only transfected with control siRNA. ${ }^{\# \#} p<0.01$ compared to the cells transfected with $\beta$-catenin siRNA along with $p$, $p^{\prime}$-DDE treatment. (B) Cell viability and (C) proliferation rate were analyzed by MTT and cell number assay. Values are percent as the mean \pm SD of three independent experiments. ${ }^{* *} p<0.01$ compared to control.

doi:10.1371/journal.pone.0112700.g003

well plates $\left(5 \times 10^{4}\right.$ cells per well $)$ and exposure to $p$, $p$-DDE for $96 \mathrm{~h}$. Total number of viable cells was counted by trypan blue exclusion method using a hemocytometer. Proliferation rate $(\%$ above control $)=($ Number of treated cells - Number of control cells)/number of control cells $\times 100$. When cells were exposed to high concentrations of $p, p^{\prime}$-DDE at $10^{-5}$ and $10^{-4} \mathrm{M}$, inhibition rate $(\%)$ in MTT assay was calculated based on the following formula: inhibition rate $(\%)=\left(\mathrm{A}_{570}\right.$ of control $-\mathrm{A}_{570}$ of treated cells) $/ \mathrm{A}_{570}$ of control $\times 100$. In cell counts, inhibition rate $(\%)=($ Number of control cells - Number of treated cells $) /$ number of control cells $\times 100$.

RNA isolation and Quantitative real-time PCR analysis

Cells were incubated with various concentrations of $p, p$ '-DDE $\left(10^{-10}, 10^{-11}, 10^{-9} \mathrm{M}\right)$ for $96 \mathrm{~h}$. In antioxidants experiments, cells were cultured in $10^{-9} \mathrm{M}$ of $p, p^{\prime}$-DDE alone or co-cultured with NAC $\left(10^{-3} \mathrm{M}\right)$, SOD $(100 \mathrm{U} / \mathrm{ml})$ or CAT $(500 \mathrm{U} / \mathrm{ml})$ for $96 \mathrm{~h}$. Total RNA was extracted from treated cells using trizol reagent. $1 \mu \mathrm{g}$ of DNA-free total RNAs was reverse transcribed using
PrimeScript RT Master Mix. For RT-PCR assay, $25 \mu \mathrm{L}$ reaction mixture containing $4 \mu \mathrm{L}$ cDNA, $1 \mu \mathrm{L}$ primers and $12.5 \mu \mathrm{L}$ SYBR Premix Ex Taq were used to detect double-stand DNA synthesis. The forward $(\mathrm{F})$ and reverse $(\mathrm{R})$ primers were as follows: PTCHl $(\mathrm{F})$ : 5'-ACGAGAATGGGTCGACGACAA-3'; PTCH1 (R): 5'-AAAGTCTGAGGTGTCGGGCAA-3'; Noxl (F):

5'-CACAAGAAAAATCGTTGGGTCAA-3'; Noxl (R):

5'-GACAGCAGATTGCGACACACA-3'; p22 ${ }^{\text {phox }}$ (F):

5'-CGCTGGCGTCGGCGTGATCGTCA-3'; p22 ${ }^{\text {phox }}$ (R):

5'-AGGCACAGCGGCCAGTAGGTAGAT-3'; p40 phox (F):

5'-TGAACAGCTTCGGGATGATG-3'; p40 ${ }^{\text {phox }}$ (R):

5'-TGAAGGCTCTCTTCTCGTCGAT-3'; p47 $7^{\text {phox }}$ (F):

5'-GTCAGATGAAAGCAAAGCGA-3'; p47 $7^{\text {phox }}$ (R):

5'-CATAGTTGGGGTCAGGGTCT-3'; p67 $7^{\text {phox }}$ (F):

5'-ATCAGCGTCTGGAATGAAGGGG-3'; p67 ${ }^{\text {phox }}$ (R):

5'-GCAGCGAATGTTGAAGCAAATCG-3'; GAPDH (F):

5'-GCACGGTCAAGGCTGAGAAC-3'; GAPDH (R):

5'-GGACGGTCAAGGCTGAGAAC-3' . 
A

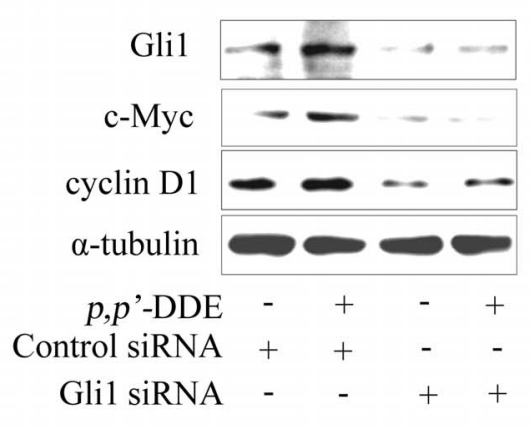

B

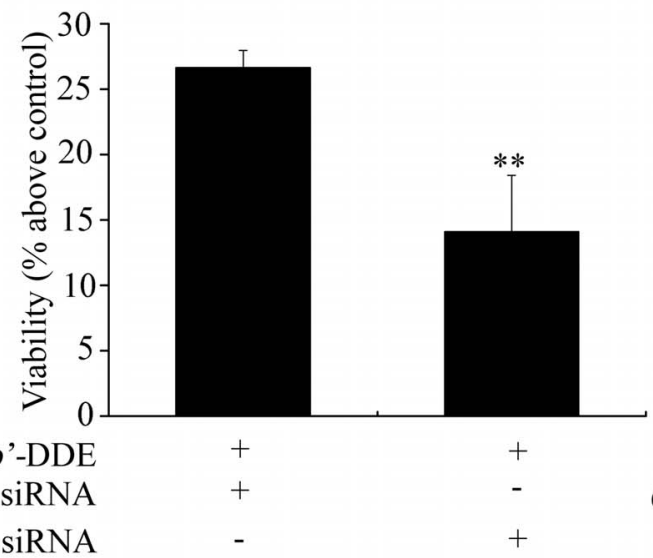

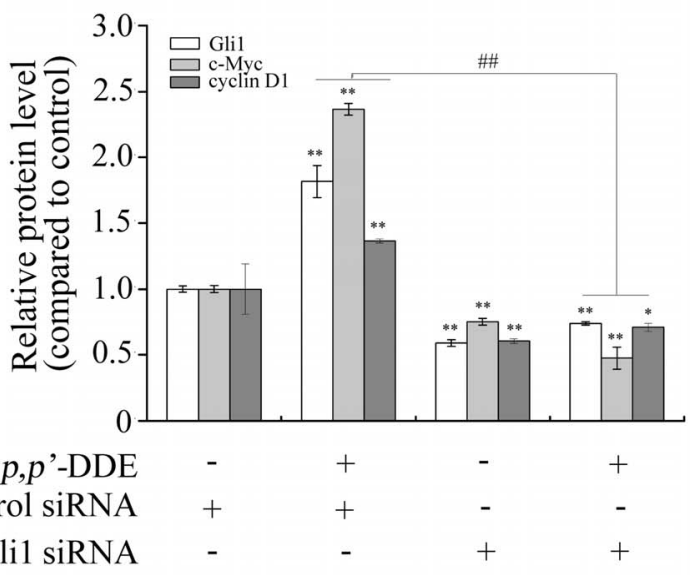

$\mathrm{C}$

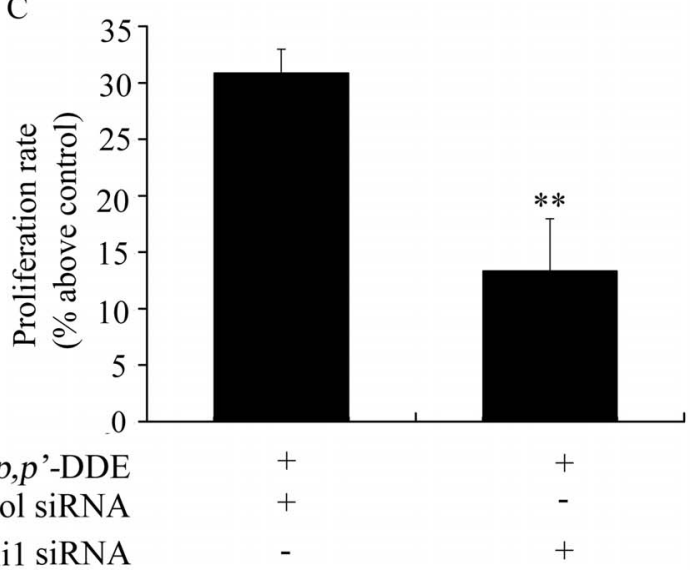

Figure 4. Inhibition of Hedgehog/Gli1 signaling blocks $p, p^{\prime}-\mathrm{DDE}$-induced DLD1 cell proliferation. After DLD1 cells were transfected with control siRNA or Gli1 siRNA, followed by treating with $p, p^{\prime}$-DDE $\left(10^{-9} \mathrm{M}\right)$ for $96 \mathrm{~h}$, (A) Protein levels of Gli1, c-Myc and cyclin D1 were examined by western blotting. $\alpha$-tubulin was used as a control. Grayscale scan analysis of western blot bands from three independent experiments were shown in right panel of graph. ${ }^{*} p<0.05$ and ${ }^{* *} p<0.01$ compared to the cells only transfected with control siRNA. $\# \# p<0.01$ compared to the cells transfected with Gli1 siRNA along with $p, p^{\prime}$-DDE treatment. (B) Cell viability and (C) proliferation rate were analyzed by MTT and cell number assays. The results are percent as the mean $\pm \mathrm{SD}$ of three independent experiments. ${ }^{* *} p<0.01$ compared to control. doi:10.1371/journal.pone.0112700.g004

\section{Protein extraction and Western blotting}

Treated cells were lysed using western lysis buffer for $10 \mathrm{~min}$, followed by centrifugation at $13,000 \times \mathrm{g}$ for $15 \mathrm{~min}$ to precipitate insoluble material. Cytoplasmic and nuclear proteins were extracted according the instructions of cytoplasmic and nuclear protein extraction kit. Protein concentration was measured using a BCA protein kit. $40 \mu \mathrm{g}$ of cell lysates were separated by $12 \%$ SDSPAGE and transferred to nitrocellulose membranes using a BIORAD mini-transblot system. Membranes were blocked for $1 \mathrm{~h}$ in Tris-buffered saline (TBS) containing 5\% milk and Tween 20, followed by incubation with anti- $\beta$-catenin $(1: 1000)$, anti-phosphoGSK3 $\beta$ (Ser9) (1:1000), anti-phospho- $\beta$-catenin (Ser33) (1:500), anti-Gli1 (1:500), anti-c-Myc (1:500), anti-Lamin B1 (1:500), anticyclin D1 (1:500), anti-PGNA $(1: 1000)$ or anti- $\alpha$-tubulin $(1: 500)$ overnight at $4{ }^{\circ} \mathrm{C}$. Following three washes in TBS, membranes were incubated with secondary antibodies $(1: 1000)$ for $1 \mathrm{~h}$ at room temperature and incubated in chemiluminescence detection substrate for $5 \mathrm{~min}$ followed by X-ray film exposure.

\section{RNA interference}

DLD1 cells grown in 6-well plates $\left(10^{6}\right.$ cells per well) or in 96well plates $\left(10^{3}\right.$ cells per well $)$ were transfected with $100 \mathrm{nM} \beta$ catenin siRNA, Glil siRNA or non-silencing siRNA using Lipofectamine 2000 according to manufacturer's protocol. After transfection for $6 \mathrm{~h}$, cells were treated with $10^{-9} \mathrm{M}$ of $p, p^{\prime}$-DDE for $96 \mathrm{~h}$, followed by performing cell viability and western blot assay. The following siRNA were used:

$\beta$-catenin siRNA: 5'-CAGUUGUGGUUAAGGUCUUdTdT$3^{\prime}$;

Glil siRNA: 5'-CUCCACAGGCAUACAGGAUTT;

Non-silencing siRNA: 5'- TTGTCGGAACGTGTCACGT-3'.

\section{Measurement of intracellular ROS, GSH content, SOD and} CAT activities

After cells were treated with $p, p^{\prime}$-DDE $\left(10^{-9} \mathrm{M}\right)$ with or without NAC $\left(10^{-3} \mathrm{M}\right)$, SOD $(100 \mathrm{U} / \mathrm{ml})$ or CAT $(500 \mathrm{U} / \mathrm{ml})$ for $96 \mathrm{~h}$, reactive oxygen species (ROS), GSH content, superoxide dismutase (SOD) and catalase (CAT) activities were evaluated using commercial assay kits. For ROS measurements, cells were incubated with $10 \mu \mathrm{M}$ of $2^{\prime}, 7^{\prime}$-dichlorofluorescein diacetate 
A

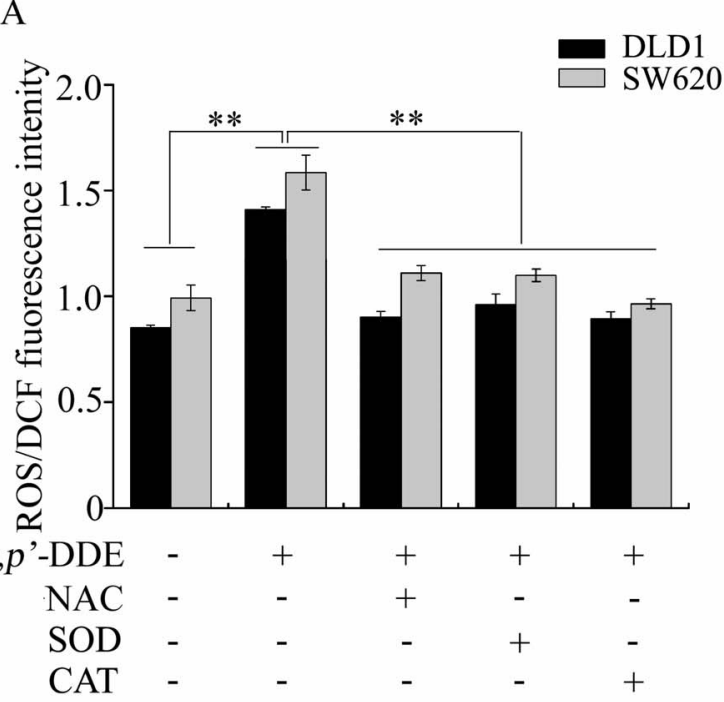

$\mathrm{C}$

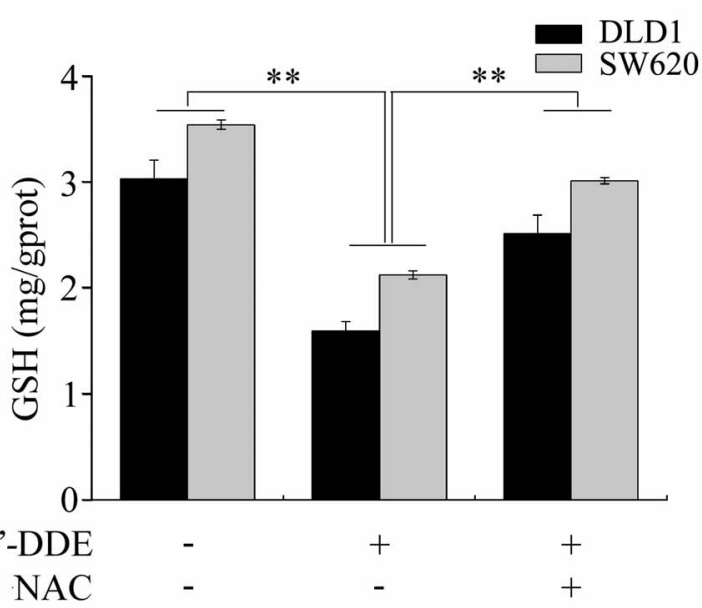

$\mathrm{E}$

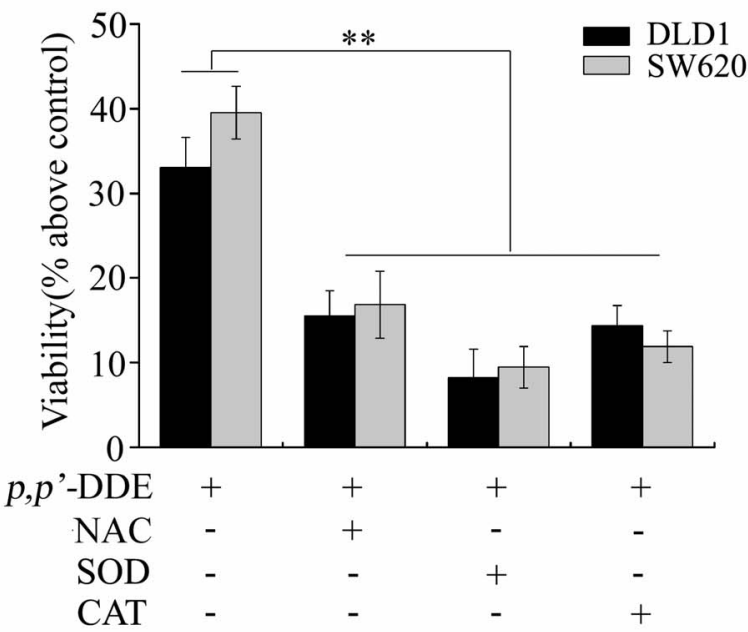

B

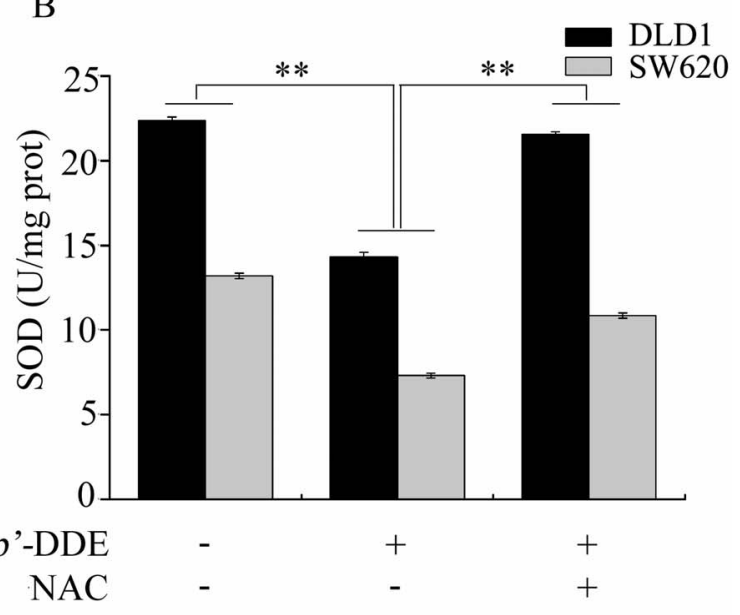

$\mathrm{D}$

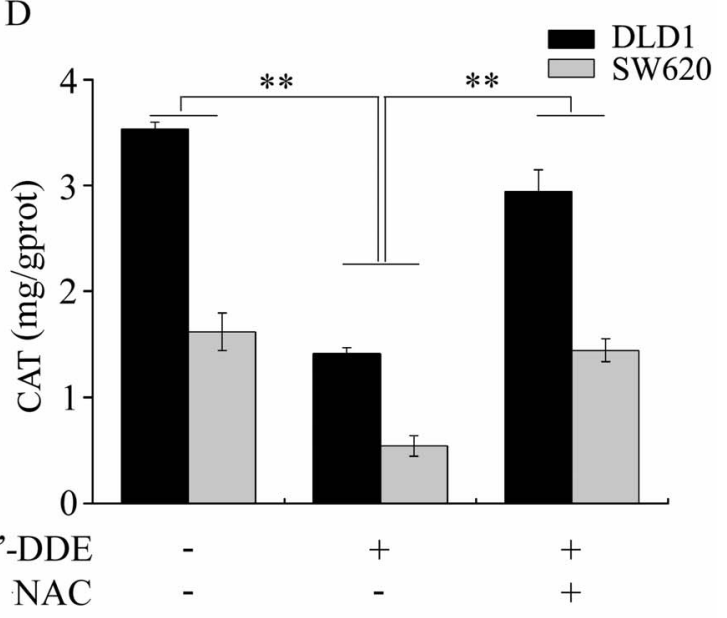

$\mathrm{F}$

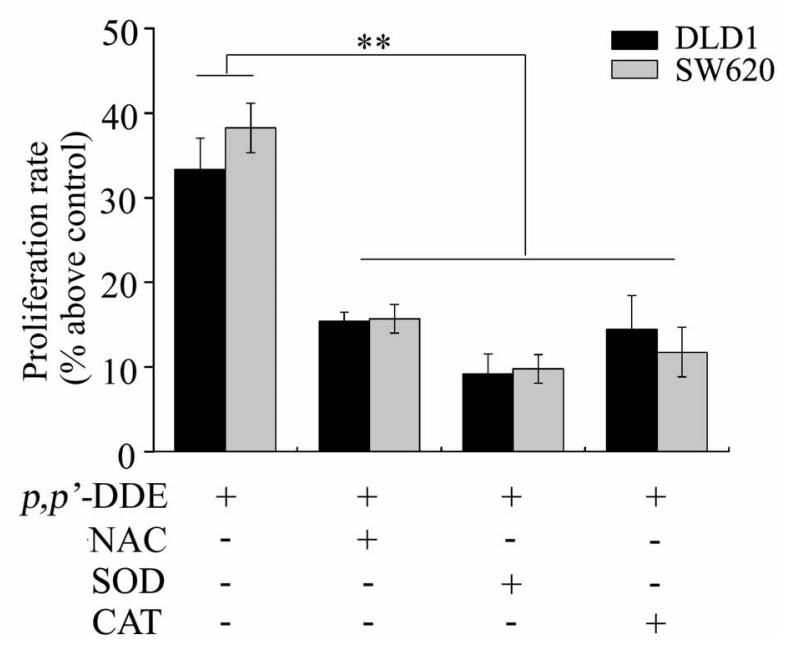

Figure 5. Oxidative stress plays a vital role in $p, p^{\prime}$-DDE-induced colorectal adenocarcinoma cell proliferation. After DLD1 or SW620 cells were treated with $p, p^{\prime}$-DDE $\left(10^{-9} \mathrm{M}\right)$ alone or co-treated with NAC $\left(10^{-3} \mathrm{M}\right)$, SOD $(100 \mathrm{U} / \mathrm{ml})$ or CAT $(500 \mathrm{U} / \mathrm{ml})$ for $96 \mathrm{~h}$, (A) ROS levels, (B) SOD activity, (C) GSH content, (D) CAT activity, (E) cell viability and (F) proliferation rate were analyzed. The results were the mean \pm SD of three independent experiments. ${ }^{*} p<0.01$ compared to the cells treated with $10^{-9} \mathrm{M} p, p^{\prime}$-DDE. doi:10.1371/journal.pone.0112700.g005 
A

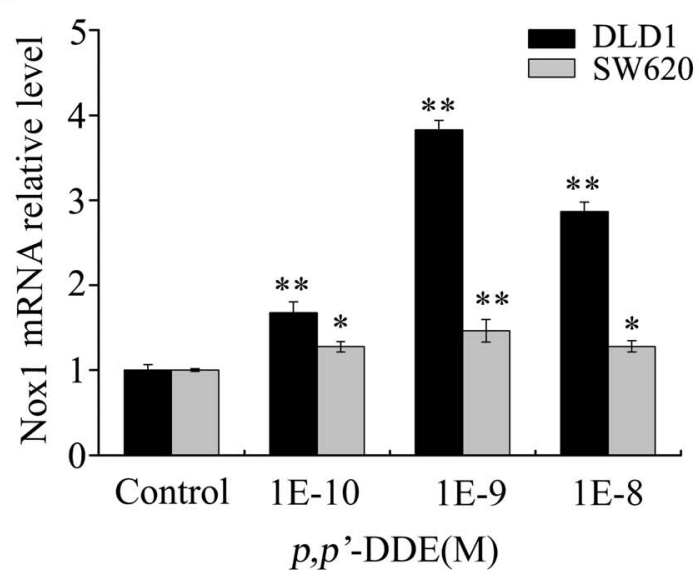

$\mathrm{C}$

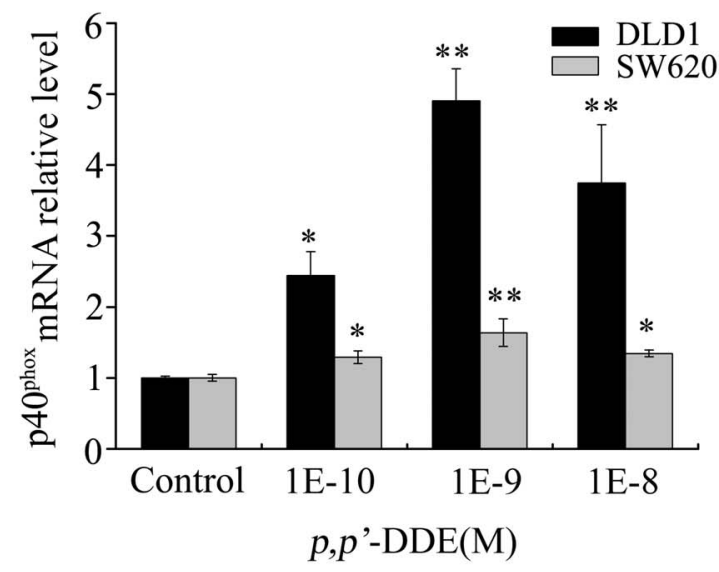

B

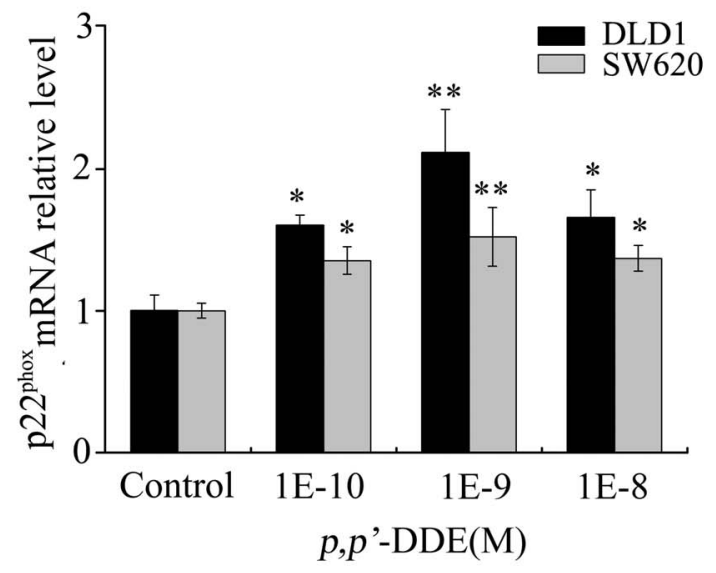

$\mathrm{D}$

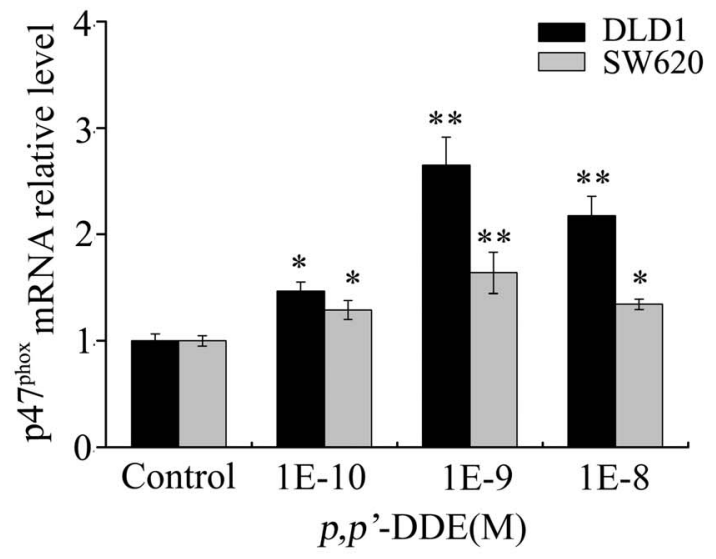

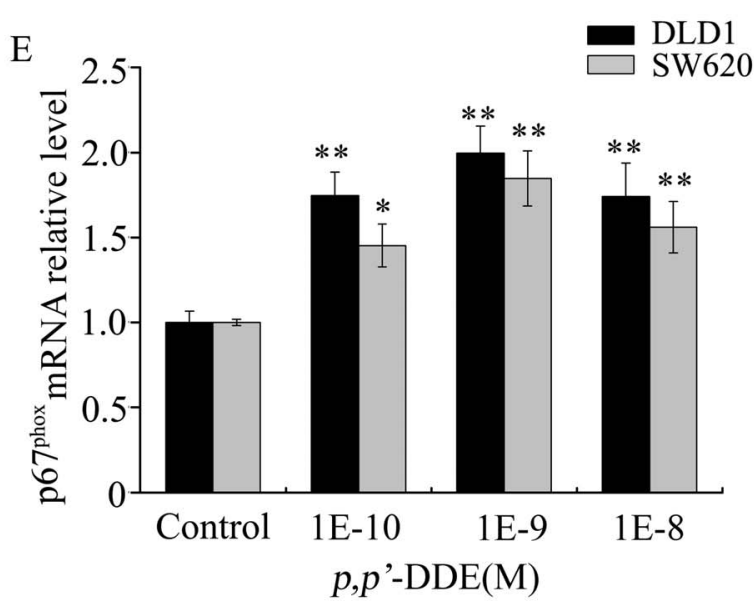

Figure 6. Effects of $p, p^{\prime}$-DDE on Nox1, $\mathrm{p}^{22^{\text {phox }}}, \mathrm{p}^{0^{\text {phox }}}, \mathrm{p} 47^{\text {phox }}$ and $\mathbf{p} 67^{\text {phox }}$ expression in colorectal adenocarcinoma cells. After DLD1 or SW620 cells were exposed to $p, p^{\prime}-D D E\left(10^{-10}, 10^{-9}, 10^{-8} \mathrm{M}\right)$ for $96 \mathrm{~h}$, the levels of Nox1 (A), p22 $2^{\text {phox }}(\mathrm{B}), \mathrm{p} 40^{\text {phox }}(\mathrm{C}), \mathrm{p} 47^{\text {phox }}(\mathrm{D})$ and $\mathrm{p} 67^{\text {phox }}$ (E) $m R N A$ expression were determined by quantitative real-time PCR and normalized to control mRNA. The data were acquired from three biologically independent experiments. Values shown were given as the \pm SD. ${ }^{*} p<0.05$ and ${ }^{* *} p<0.01$ compared to control. doi:10.1371/journal.pone.0112700.g006

(DCFH-DA) at $37^{\circ} \mathrm{C}$ for $30 \mathrm{~min}$. Cells were collected and the production of ROS was detected by changes in fluorescence due to the accumulation of DCF using a fluorescence microplate reader (Thermo Scientific varioskan flash). For GSH content, SOD and
CAT activities, cells were suspended in physiological saline (PBS), followed by ultrasound treatment and centrifugation at 6,000 rpm for $10 \mathrm{~min}$. The supernatant of cell lysates were used for experiments. GSH levels were determined at $420 \mathrm{~nm}$ using 5, 

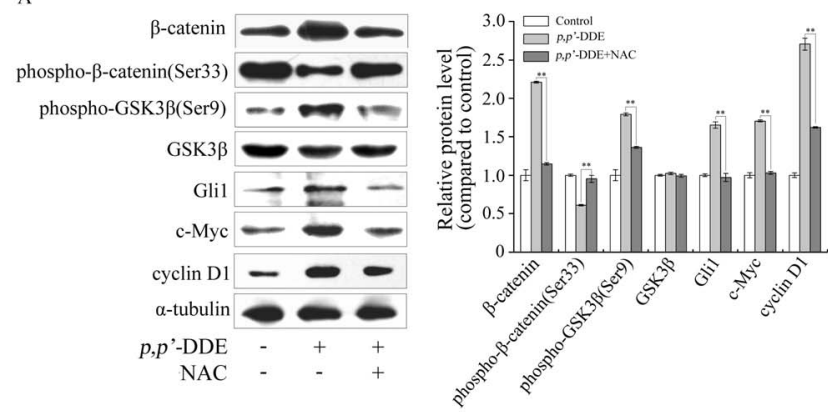

B
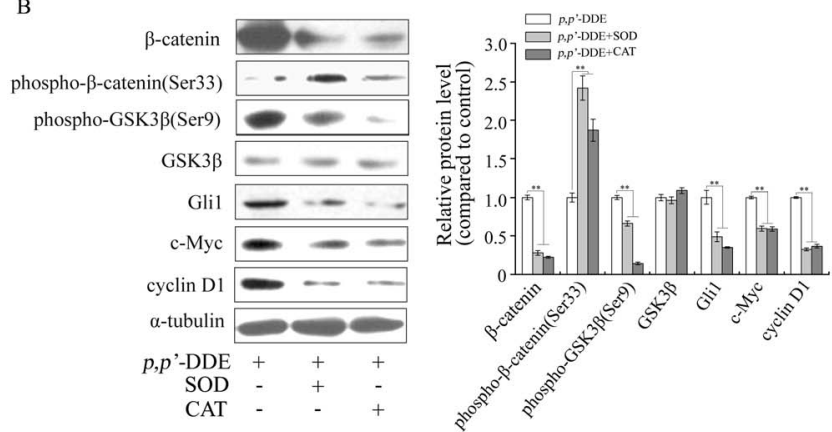

$\mathrm{C}$

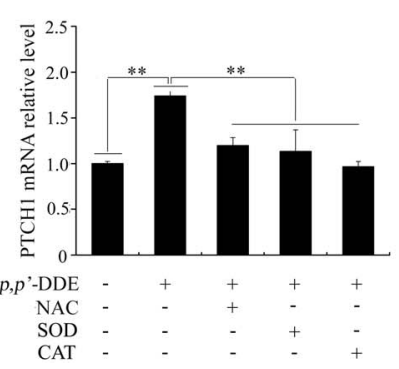

Figure 7. The antioxidants inhibit $p, p^{\prime}$-DDE-induced Wnt/ $\beta$ catenin and Hedgehog/Gli1 signalings activation in DLD1 cells. After DLD1 cells were treated with $p, p^{\prime}-\mathrm{DDE}\left(10^{-9} \mathrm{M}\right)$ alone or cotreated with NAC $\left(10^{-3} \mathrm{M}\right)(\mathrm{A})$, SOD $(100 \mathrm{U} / \mathrm{ml})$ or CAT $(500 \mathrm{U} / \mathrm{ml})(B)$ for $96 \mathrm{~h}$, western blotting was performed to analyzed $\beta$-catenin, phospho$\beta$-catenin (Ser33), phospho-GSK3 $\beta$ (Ser9), GSK3 $\beta$, Gli1, c-Myc and cyclin D1. $\alpha$-tubulin was used as the loading control. Grayscale scan analysis of western blot bands were shown in right panel of graph. (C) mRNA expression of PTCH1 was quantified by quantitative real-time PCR analysis. Relative mRNA levels were normalized with control mRNA. In (A), (B) and (C), value shown was given as the $\pm S D$ and acquired from three biologically independent experiments. ${ }^{* *} p<0.01$ compared to the cells treated with $10^{-9} \mathrm{M} p, p^{\prime}$-DDE.

doi:10.1371/journal.pone.0112700.g007

5'-dithiobis-2-nitobenzoic acid. SOD activity was examined for reduction of nitroblue tetrazolium (NBT). CAT activity was determined by the decomposition of $\mathrm{H}_{2} \mathrm{O}_{2}$.

\section{Statistical analysis}

All data were presented as means \pm standard deviation from three independent experiments. Statistical analyses used the SPSS 10 software. Data were analyzed by Student's $t$-test where two treatments were compared or one-way analysis of variance (ANOVA) with Tukey's multiple comparison tests for comparisons of more than two treatments. Statistically significant was defined as $p<0.05$.

\section{Results}

Low concentrations of $p, p^{\prime}$-DDE promote colorectal adenocarcinoma cell proliferation

To test the effects of $p, p$ '-DDE on colorectal adenocarcinoma cells, cell viability and viable cell counts were analyzed after DLD 1 or SW620 cells treated with $p, p^{\prime}$-DDE $\left(10^{-12}\right.$ to $\left.10^{-4} \mathrm{M}\right)$ for $96 \mathrm{~h}$. MTT and cell count assays showed that $p, p^{\prime}$-DDE exposure at $10^{-4} \mathrm{M}$ significantly inhibited cell viability and decreased viable cell counts in both DLD1 and SW620 cells (Fig. S1). However, at $10^{-5}$ and $10^{-6} \mathrm{M}$ no significant effects were observed (Fig. S1 and 1). When colorectal adenocarcinoma cells were exposed to lower concentrations of $p, p^{\prime}$-DDE $\left(10^{-12}\right.$ to $\left.10^{-7} \mathrm{M}\right)$, cell viability and viable cell counts were significantly increased (Fig. 1). Treatment with $10^{-9} \mathrm{M} p, p$-DDE resulted in the biggest increase in cell viability and viable cell counts. Taken together, these results indicated that low concentrations of $p, p^{\prime}-\operatorname{DDE}\left(10^{-12}\right.$ to $\left.10^{-7} \mathrm{M}\right)$ markedly promote colorectal adenocarcinoma cell proliferation.

$p, p^{\prime}$-DDE stimulates both Wnt/ $\beta$-catenin and Hedgehog/ Gli1 signalings in colorectal adenocarcinoma cells

Both Wnt/ $\beta$-catenin and Hedgehog/Glil signalings are abnormal activated in colorectal cancer [25-28]. To elucidate the mechanism of $p, p$-DDE in promoting colorectal adenocarcinoma cell proliferation, both Wnt/ $\beta$-catenin and Hedgehog/Glil signalings were examined after cells treated with $p, p$ 'DDE $\left(10^{-10}, 10^{-9}\right.$ and $\left.10^{-8} \mathrm{M}\right)$ for $96 \mathrm{~h}$. As shown in Fig. 2A and $\mathrm{S} 2 \mathrm{~A}, p, p$-DDE treatment resulted in increased $\beta$-catenin and phospho-GSK3 $\beta$ (Ser9) levels along with decreased phospho- $\beta$ catenin (Ser33) levels in DLD1 or SW620 cells. It suggested that $p, p$-DDE stimulated Wnt/ $\beta$-catenin signaling in colorectal adenocarcinoma cells. In addition, $p, p^{\prime}$-DDE exposure increased Glil protein level and mRNA level of PATCH1 (Fig. 2A, 2B and S2), which suggested $p, p$-DDE could stimulate Hedgehog/Glil signaling. $\beta$-catenin or Glil, acting as nuclear executors of Wnt/ $\beta$ catenin or Hedgehog/Glil signaling, inputs cell nuclear and induces target gene transcription [25]. Therefore, the intracellular distribution of $\beta$-catenin or Glil after DLDl cells exposed to $p, p$ 'DDE was examined. The data indicated that $p, p$-DDE exposure led to the accumulation of both $\beta$-catenin and Glil in the nucleus (Fig. 2C).

Activation of Wnt/ $\beta$-catenin and Hedgehog/Glil signalings results in overexpression of downstream c-Myc and cyclin D1, which are involved in cancer cell proliferation [29,32,33]. Therefore, c-Myc, cyclin D1 and downstream proliferation effector PCNA were examined after $p, p$-DDE treatment. The results showed that c-Myc, cyclin Dl and PCNA were up regulated in $p, p$ '-DDE-treated cells (Fig. 2A and S2A). These results suggested that overexpression of both c-Myc and cyclin D1 were involved in $p, p^{\prime}$-DDE-induced colorectal adenocarcinoma cell proliferation.

\section{Blockage of Wnt/ $\beta$-catenin or Hedgehog/Gli1 signaling prevents $p, p^{\prime}$-DDE-induced colorectal adenocarcinoma cell proliferation}

To further examine the role of Wnt/ $\beta$-catenin or Hedgehog/ Glil signaling in $p, p$-DDE-induced colorectal adenocarcinoma cell proliferation. $\beta$-catenin or Glil siRNA was used to reduce $\beta$ catenin or Glil levels and thereby inhibited Wnt/ $\beta$-catenin or Hedgehog/Glil pathway in DLD1 cells. Fig. 3 showed that $\beta$ catenin siRNA blocked $p, p$ '-DDE-induced DLD1 cell proliferation as well as overexpression of c-Myc and cyclin D1. Similar to the impact of $\beta$-catenin siRNA, $p, p^{\prime}$-DDE-induced DLD1 cell 


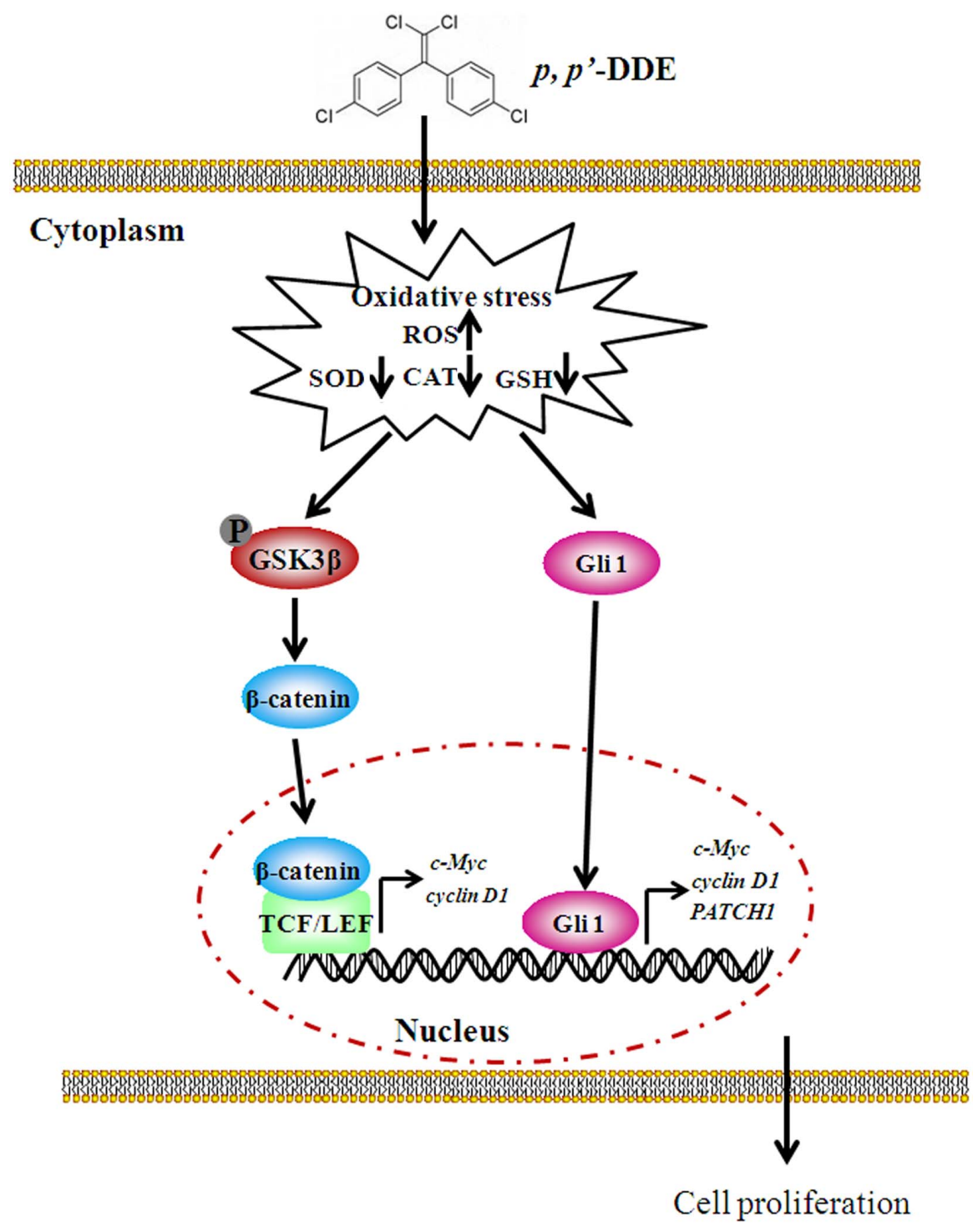

Figure 8. Proposed diagram of $p, p^{\prime}$-DDE-induced colorectal adenocarcinoma cell proliferation. At low concentrations, $p, p^{\prime}-\mathrm{DDE}$ promotes colorectal adenocarcinoma cell proliferation through c-Myc and cyclin D1 overexpression resulted from the stimulation of Wnt/ $\beta$-catenin and Hedgehog/Gli1 signalings, which were mediated by oxidative stress. doi:10.1371/journal.pone.0112700.g008

proliferation and overexpression of c-Myc and cyclin D1 were inhibited by Glil siRNA (Fig. 4). These results suggested both Wnt/ $\beta$-catenin and Hedgehog/Glil signalings play important roles in $p, p$ '-DDE-induced colorectal adenocarcinoma cell proliferation.

Oxidative stress plays a vital role in $p, p^{\prime}$-DDE-induced colorectal adenocarcinoma cell proliferation

Next, we evaluated the components of oxidative stress in $p, p$ 'DDE treated cells. As shown in Fig. 5A, p,p'-DDE exposure induced 1.7 and 1.6-fold increase in ROS levels in DLD1 and SW620 cells respectively, compared to the negative control. SOD activities were reduced 1.6 and 1.8-fold in p,p'-DDE-stimulated DLD1 and SW620 cells, respectively (Fig. 5B). We also found that both GSH content and CAT activity were reduced in $p, p$ '-DDEstimulated cells (Fig. 5C and D). GSH content and CAT activities were reduced 1.9 and 2.5-fold in $p$, $p$-DDE-treated DLD1 cells (Fig. 5C and D). In SW620 cells, p,p'-DDE led to 1.7 and 3.0-fold decrease in GSH content and CAT activities (Fig. 5C and D). These results indicated that $p, p$ '-DDE exposure stimulated oxidative stress in colorectal adenocarcinoma cells. Nicotinamide adenine dinucleotide phosphate (NADPH) oxidases are key enzymes responsible for ROS generation [39]. We examined the effects of $p, p$-DDE on the expression of NADPH oxidase subunits, including Nox $1, \mathrm{p} 22^{\text {phox }}, \mathrm{p} 40^{\text {phox }}, \mathrm{p} 47^{\text {phox }}$ and $\mathrm{p} 67^{\text {phox }}$. As shown in Fig. 6, p,p'-DDE treatment increased mRNA levels of Noxl, $\mathrm{p} 22^{\text {phox }}, \mathrm{p} 40^{\text {phox }}, \mathrm{p} 47^{\text {phox }}$ and $\mathrm{p} 67^{\text {phox }}$ in DLD1 or SW620 cells. These results suggested that activation of NADPH oxidase is involved in $p, p$-DDE-induced ROS generation in colorectal adenocarcinoma cells.

To further determine the role of oxidative stress in $p, p$ '-DDEinduced colorectal adenocarcinoma cell proliferation, ROS inhibitor NAC, antioxidant enzyme SOD or CAT was applied to reduce oxidative stress. As shown in Fig. 5, p,p'-DDE-induced oxidative stress was significantly reduced after NAC, SOD or CAT treatment (Fig. 5A-D). In addition, $p$, $p$ '-DDE-induced adenocar- 
cinoma cell viability and proliferation were decreased by NAC, SOD or CAT (Fig. 5E and F). Above results suggested that oxidative stress plays a vital role in $p, p$ '-DDE-induced colorectal adenocarcinoma cell proliferation.

\section{Inhibition of oxidative stress decreases $p, p^{\prime}$-DDE induced Wnt/ $\beta$-catenin and Hedgehog/Gli1 signalings activation}

Accumulated evidences showed both Wnt/ $\beta$-catenin and Hedgehog/Glil signalings could been stimulated by oxidative stress $[36,40-45]$. We speculated that both $\mathrm{Wnt} / \beta$-catenin and Hedgehog/Glil signalings could been mediated by $p, p$-DDE through oxidative stress. To verify this hypothesis, cells were treated with $p, p$-DDE combined with NAC, SOD or CAT for $96 \mathrm{~h}$. The results showed treatment with NAC, SOD or CAT prevented $p, p$-DDE-induced the up regulation of $\beta$-catenin, phospho-GSK3 $\beta$ (Ser9), Gli1, PATCH1, c-Myc and cyclin D1 as well as down regulation of phospho- $\beta$-catenin (Ser33) (Fig. 7 and S3). These results suggested that both $\mathrm{Wnt} / \beta$-catenin and Hedgehog/Glil signalings were mediated by oxidative stress in $p, p$-DDE-stimulated cells.

\section{Discussion}

$p, p$-DDE, the major metabolite of DDT, is a hazardous persistent chemicals presented in environment, and attracts extensive public attentions on its adverse health effects. In the present study, we provide experimental supports for $p, p$-DDE promoting the development of colorectal cancers through inducing cancer cell proliferation. The possible role of $p, p$ '-DDE in inducing colorectal cell proliferation is summarized in Fig. 8. At low concentrations, $p, p$-DDE exposure stimulates oxidative stress, followed by activating Wnt/ $\beta$-catenin and Hedgehog/Glil signalings. Abnormal activation of two-crucial pathways results in overexpression of downstream target proteins c-Myc and cyclin D1 and thus induces the proliferation of colorectal cancer cells.

Our results indicated that $p, p$ '-DDE exposure at low concentrations $\left(10^{-12}\right.$ to $\left.10^{-7} \mathrm{M}\right)$ significantly promoted colorectal adenocarcinoma cell proliferation. However, high concentration of $p, p$ '-DDE $\left(10^{-4} \mathrm{M}\right)$ significantly inhibited cell viability and viable cell counts. These results suggested that low concentrations of $p, p$ '-DDE present the inducibility on colorectal adenocarcinoma cell proliferation. Previous observations found high concentrations of $p$, p'-DDE $\left(>3 \times 10^{-5} \mathrm{M}\right)$ induced rat sertoli cell apoptosis $[34,46]$, which were consistent with our results.

It has been known that aberrant Wnt/ $\beta$-catenin signaling is discovered in about $80 \%$ colorectal cancers $[25,26]$. In colorectal cancers, mutations in components of $\mathrm{Wnt} / \beta$-catenin pathways such as adenomatous polyposis coli (APC), Axin and $\beta$-catenin are common and render $\beta$-catenin difficult for degradation by cellular proteosomes [45]. GSK $3 \beta$ is a serine/threonine protein kinase and is inhibited by phosphorylation at Ser 9 residual [47]. GSK3 $\beta$ destabilizes $\beta$-catenin by phosphorylating it at Ser33, 37 and Thr41 [48]. Our present findings revealed that total and nuclear $\beta$-catenin were significantly increased in $p, p$-DDE-stimulated cells. $p, p$-DDE exposure also led to unregulated phosphorylation of GSK-3 $\beta$ at Ser 9 along with reduced phosphorylation of $\beta$ catenin at Ser 33 . These results suggested GSK-3 $\beta$ activity was inhibited and thereby led to $\beta$-catenin stabilization during $p, p$ 'DDE-induced colon cancer cell proliferation. Hedgehog/Glil signaling is implicated to be important in the maintenance of colon tumor $[27,28,49]$. Hedgehog/Glil signaling related components, PTCH1 and Glil, are over-expressed in colon tumor [27,50-52]. Our results showed that $p, p$-DDE exposure markedly upregulated total and nucleus Glil, as well as PTCH1 mRNA levels. PTCH1 is not only the component of Hedgehog/Glil signaling but also regulated by Glil [53]. It is likely that increased Glil induced by $p$, $p$ 'DDE elevated PTCH1 mRNA levels. It has been reported that both $\beta$-catenin and Glil mediate proto-oncogenes including $c$-myc and cyclin D1 [29,32,33]. This study found both c-myc and cyclin Dl were increased after $p, p$ '-DDE exposure, and knockdown of $\beta$-catenin or Glil prevented $p, p$-DDE-induced generation. These results indicated c-myc and cyclin Dl were regulated by Wnt/ $\beta$-catenin and Hedgehog/Glil signalings in $p, p$ '-DDEstimulated colorectal adenocarcinoma cells.

$p, p$-DDE-induced toxicity is associated with oxidative stress. $p, p$-DDE can induce apoptosis by elevating ROS production [46,54]. In addition, $p, p$-DDE exposure also could result in increased MDA (a product of lipid peroxidation) as well as decreased SOD and GSH-Px activities [46,55]. In this study, we found elevated ROS production, lower GSH content, SOD and CAT activities in $p, p$-DDE-treated colorectal adenocarcinoma cells. These results were consistent with previous investigation. NADPH oxidase is a membrane-localized enzyme responsible for ROS generation. NADPH oxidase utilize NADPH as an electron donor to generate superoxide $\left(\mathrm{O}_{2}{ }^{-}\right)$[56]. Various NADPH oxidase isoforms (Nox1-Nox7) have been found. Nox1 is highly expressed in colonic epithelial cells and integrates Wnt/ $\beta$-catenin and Notchl signals to control colon progenitor cell proliferation and fate [57]. In human colon cancers, Nox1 is overexpressed and correlates with ROS-dependent cancer invasion [58,59]. It has been reported that NADPH oxidase activation is involved in arsenic-induced cell transformation and tumorigenesis in human colorectal adenocarcinoma cells [41]. Our results showed that $p, p$ 'DDE increased expression of Nox $1, \mathrm{p} 22^{\text {phox }}, \mathrm{p} 40^{\text {phox }}, \mathrm{p} 47^{\text {phox }}$ and $\mathrm{p} 67^{\text {phox }}$. These observation suggested that NADPH oxidase activation plays crucial role in $p, p^{\prime}$-DDE induced oxidative stress in colorectal adenocarcinoma cells. Many investigators have suggested the involvement of oxidative stress in toxicant-induced carcinogenesis. For example, cadmium, arsenic and chromium could promote tumorigenesis via an ROS-mediated pathway $[36,41,42]$. Our previous study demonstrated that $p, p$ '-DDT, precursor of $p, p$-DDE induced colorectal cancer growth through oxidative stress-mediated pathways [37]. To verify the involvement of oxidative stress in $p, p$ '-DDE-induced colorectal adenocarcinoma cell proliferation, cells were co-exposured to both $p, p^{\prime}-$ DDE and NAC, SOD or CAT. Treatment with NAC, SOD or CAT reduced $p, p$-DDE-induced cell proliferation, which indicated that oxidative stress plays important role in $p, p$ '-DDE-induced colorectal adenocarcinoma cell proliferation.

Our study found that oxidative stress, Wnt/ $\beta$-catenin and Hedgehog/Glil signalings were involved in $p, p$-DDE-induced colorectal adenocarcinoma cell proliferation. Many studies found oxidative stress-mediated signalings include both Wnt/ $\beta$-catenin and Hedgehog/Glil signalings. Zhang et al reported that arsenic induced colorectal adenocarcinoma cell transformation and tumorigeneis through ROS-mediated $\mathrm{Wnt} / \beta$-catenin signaling [41]. ROS regulated arsenic and chromium-induced tumorigenesis via $\mathrm{Wnt} / \beta$-catenin signaling in a mouse colitis-associated colorectal cancer model [36]. Hedgehog/Glil signaling was activated under $\mathrm{H}_{2} \mathrm{O}_{2}$-induced oxidative stress in cultured astrocytes [60]. To clarify whether both $\mathrm{Wnt} / \beta$-catenin and Hedgehog/Glil signalings are mediated through oxidative stress in $p, p^{\prime}$-DDE-stimulated cells, ROS inhibitor NAC, antioxidant enzyme SOD or CAT was employed to reduce oxidative stress, followed by assessing both Wnt/ $\beta$-catenin and Hedgehog/Glil signalings. Treatment of NAC, SOD or CAT not only attenuated the induction of $\beta$-catenin, phospho-GSK3 $\beta$ (Ser9), Glil, PATCH1, c-Myc and cyclin Dl, but also prevented the 
downregulation of phospho- $\beta$-catenin (Ser33). These results strongly suggested that oxidative stress activated both $\mathrm{Wnt} / \beta$ catenin and Hedgehog/Glil signalings.

In conclusion, our study demonstrates for the first time that $p, p$ 'DDE exposure stimulates proliferation of colorectal cell proliferation, leading to colorectal cancer progression. In vitro exposure of $p, p$ '-DDE can enhance oxidative stress, then induce activation in Wnt/ $\beta$-catenin and Hedgehog/Glil signalings. These effects result in increased expression of downstream target proteins c-Myc and cyclin D1 and thereby induce colorectal cell proliferation. The present study provides important data for further study of cancer development resulting from xenobiotic compounds.

\section{Supporting Information}

Figure $S 1$ Effects of high concentrations of $p, p$ '-DDE on colorectal adenocarcinoma cell proliferation. After DLD 1 or SW620 cells were exposed to $p, p$-DDE $\left(10^{-5}\right.$ and $\left.10^{-4} \mathrm{M}\right)$ for $96 \mathrm{~h}$, inhibition rate $(\%)$ were determined using MTT (A) and cell number assays (B), respectively. Values are percent as the mean \pm $\mathrm{SD}$ of three independent experiments. $* * p<0.01$ compared to control cells.

(TIF)

Figure S2 $\boldsymbol{p}, \boldsymbol{p}$ '-DDE upregulates Wnt/ $\beta$-catenin and Hedgehog/Gli1 signalings in SW620 cells. After SW620 cells were treated with $p, p^{\prime}$-DDE $\left(10^{-10}, 10^{-9}, 10^{-8} \mathrm{M}\right)$ for $96 \mathrm{~h}$, (A) western blotting was performed to analyze $\beta$-catenin, phospho$\beta$-catenin (Ser33), phospho-GSK3 $\beta$ (Ser9), GSK3 $\beta$, Glil, c-Myc,

\section{References}

1. Gunasekaran K, Sahu SS, Jambulingam P, Das PK (2005) DDT indoor residual spray, still an effective tool to control Anopheles fluviatilis-transmitted Plasmodium falciparum malaria in India. Trop Med Int Health 10: 160-168.

2. Rogan WJ, Chen A (2005) Health risks and benefits of bis(4-chlorophenyl)-1,1,1trichloroethane (DDT). Lancet 366: 763-773.

3. Arrebola JP, Cuellar M, Claure E, Quevedo M, Antelo SR, et al. (2012) Concentrations of organochlorine pesticides and polychlorinated biphenyls in human serum and adipose tissue from Bolivia Environ Res 112: 40-47.

4. Galassi S, Bettinetti R, Neri MC, Falandysz J, Kotecka W, et al. (2008) pp'DDE contamination of the blood and diet in central European populations. Sci Total Environ 390: 45-52.

5. Waliszewski SM, Caba M, Herrero-Mercado M, Saldariaga-Norena H, Meza E, et al. (2011) Monitoring of organochlorine pesticide residue levels in adipose tissue of Veracruz, Mexico inhabitants. Bull Environ Contam Toxicol 87: 539544.

6. Wang N, Shi L, Kong D, Cai D, Cao Y, et al. (2011) Accumulation levels and characteristics of some pesticides in human adipose tissue samples from Southeast China. Chemosphere 84: 964-971.

7. Colosio C, Tiramani M, Maroni M (2003) Neurobehavioral effects of pesticides: state of the art. Neurotoxicology 24: 577-591.

8. Ribas-Fito N, Cardo E, Sala M, Eulalia de Muga M, Mazon C, et al. (2003) Breastfeeding, exposure to organochlorine compounds, and neurodevelopment in infants. Pediatrics 111: e580-585.

9. Rocha-Amador D, Navarro M, Trejo-Acevedo A, Carrizales L, PerezMaldonado I, et al. (2009) Use of the Rey-Osterrieth Complex Figure Test for neurotoxicity evaluation of mixtures in children. Neurotoxicology 30: 11491154 .

10. Li J, Li N, Ma M, Giesy JP, Wang Z (2008) In vitro profiling of the endocrine disrupting potency of organochlorine pesticides. Toxicol Lett 183: 65-71.

11. De Jager C, Farias P, Barraza-Villarreal A, Avila MH, Ayotte P, et al. (2006) Reduced seminal parameters associated with environmental DDT exposure and p,p'-DDE concentrations in men in Chiapas, Mexico: a cross-sectional study. J Androl 27: 16-27.

12. Beard J (2006) DDT and human health. Sci Total Environ 355: 78-89.

13. Mrema EJ, Rubino FM, Brambilla G, Moretto A, Tsatsakis AM, et al. (2013) Persistent organochlorinated pesticides and mechanisms of their toxicity. Toxicology 307: 74-88.

14. Jemal A, Bray F, Center MM, Ferlay J, Ward E, et al. (2011) Global cancer statistics. CA Cancer J Clin 61: 69-90.

15. Watson AJ, Collins PD (2011) Colon cancer: a civilization disorder. Dig Dis 29: 222-228.

16. Bazensky I, Shoobridge-Moran C, Yoder LH (2007) Colorectal cancer: an overview of the epidemiology, risk factors, symptoms, and screening guidelines. Medsurg Nurs 16: 46-51. cyclin D1 and PCNA levels. $\alpha$-tubulin was used as the loading control. (B) Quantitative real-time PGR was performed to determine the level of PTCH1 mRNA expression. Relative mRNA levels were normalized with control mRNA. Values shown were given as the $\pm \mathrm{SD}$ and acquired from three independent experiments. ${ }^{*} * p<0.01$ compared to control.

(TIF)

Figure S3 Effects of antioxidants on $p, p$ '-DDE-induced Wnt/ $\beta$-catenin and Hedgehog/Gli1 signalings activation in SW620 cells. (A) After SW620 cells were treated with $p, p$ 'DDE $\left(10^{-9} \mathrm{M}\right)$ alone or co-treated with NAC $\left(10^{-3} \mathrm{M}\right)$, SOD $(100 \mathrm{U} / \mathrm{ml})$ or CAT $(500 \mathrm{U} / \mathrm{ml})$ for $96 \mathrm{~h}$, western blotting was performed to analyzed $\beta$-catenin, phospho- $\beta$-catenin (Ser33), phospho-GSK3 $\beta$ (Ser9), GSK3 $\beta$, Glil, c-Myc and cyclin D1. $\alpha-$ tubulin was used as the loading control. (B) mRNA expression of PTCH1 was determined by quantitative real-time PCR analysis and normalized to control mRNA. Values were presented as the \pm $\mathrm{SD}$ and acquired from three independent experiments. $* * p<0.01$ compared to the cells treated with $10^{-9} \mathrm{M} p, p^{\prime}$-DDE.

(TIF)

\section{Author Contributions}

Conceived and designed the experiments: LS ZL WL. Performed the experiments: LS JL XJ. Analyzed the data: LS JL. Contributed reagents/ materials/analysis tools: LS ZL MZ. Contributed to the writing of the manuscript: LS MZ ZL.

17. Wilmink AB (1997) Overview of the epidemiology of colorectal cancer. Dis Colon Rectum 40: 483-493.

18. Chen K, Zhao YW, Ma XY, Zhang LJ, Zheng S (2004) Relationship between organochlorine pollution in soil and rice and the incidence of colorectal cancer in Jiashan county, Zhejiang province. Zhonghua Liu Xing Bing Xue Za Zhi 25: 479-483.

19. Jaga K (1999) Serum organochlorine pesticide levels in patients with colorectal cancer in Egypt. Arch Environ Health 54: 217-218.

20. Soliman AS, Smith MA, Cooper SP, Ismail K, Khaled H, et al. (1997) Serum organochlorine pesticide levels in patients with colorectal cancer in Egypt. Arch Environ Health 52: 409-415.

21. El-Tawil AM (2010) Colorectal cancer and pollution. World J Gastroenterol 16: 3475-3477.

22. Hoar SK, Blair A, Holmes FF, Boysen C, Robel RJ (1985) Herbicides and colon cancer. Lancet 1: 1277-1278.

23. Caldwell GG, Cannon SB, Pratt CB, Arthur RD (1981) Serum pesticide levels in patients with childhood colorectal carcinoma. Cancer 48: 774-778.

24. Howsam M, Grimalt JO, Guino E, Navarro M, Marti-Rague J, et al. (2004) Organochlorine exposure and colorectal cancer risk. Environ Health Perspect 112: $1460-1466$

25. Polakis $\mathrm{P}$ (2000) Wnt signaling and cancer. Genes Dev 14: 1837-1851.

26. Bienz M, Clevers H (2000) Linking colorectal cancer to Wnt signaling. Cell 103: 311-320.

27. Bian YH, Huang SH, Yang L, Ma XL, Xie JW, et al. (2007) Sonic hedgehogGlil pathway in colorectal adenocarcinomas. World J Gastroenterol 13: 1659 1665.

28. Yoshikawa K, Shimada M, Miyamoto H, Higashijima J, Miyatani T, et al. (2009) Sonic hedgehog relates to colorectal carcinogenesis. J Gastroenterol 44: 1113-1117.

29. Moon RT, Kohn AD, De Ferrari GV, Kaykas A (2004) WNT and beta-catenin signalling: diseases and therapies. Nat Rev Genet 5: 691-701.

30. Katoh Y, Katoh M (2006) Hedgehog signaling pathway and gastrointestinal stem cell signaling network. Int J Mol Med 18: 1019-1023.

31. Lum L, Beachy PA (2004) The Hedgehog response network: sensors, switches, and routers. Science 304: 1755-1759.

32. Yoon JW, Kita Y, Frank DJ, Majewski RR, Konicek BA, et al. (2002) Gene expression profiling leads to identification of GLI1-binding elements in target genes and a role for multiple downstream pathways in GLI1-induced cell transformation. J Biol Chem 277: 5548-5555.

33. Lobjois V, Benazeraf B, Bertrand N, Medevielle F, Pituello F (2004) Specific regulation of cyclins D1 and D2 by FGF and Shh signaling coordinates cell cycle progression, patterning, and differentiation during early steps of spinal cord development. Dev Biol 273: 195-209. 
34. Shi Y, Song Y, Wang Y, Liang X, Hu Y, et al. (2009) p,p'-DDE induces apoptosis of rat Sertoli cells via a FasL-dependent pathway.J Biomed Biotechnol 2009: 181282.

35. Yang J, Li TZ, Xu GH, Luo BB, Chen YX, et al. (2013) Low-concentration capsaicin promotes colorectal cancer metastasis by triggering ROS production and modulating Akt/mTOR and STAT-3 pathways. Neoplasma 60: 364-372.

36. Wang X, Mandal AK, Saito H, Pulliam JF, Lee EY, et al. (2012) Arsenic and chromium in drinking water promote tumorigenesis in a mouse colitis-associated colorectal cancer model and the potential mechanism is ROS-mediated Wnt/ beta-catenin signaling pathway. Toxicol Appl Pharmacol 262: 11-21.

37. Song L, Zhao J, Jin X, Li Z, Newton IP, et al. (2014) The organochlorine p,p'dichlorodiphenyltrichloroethane induces colorectal cancer growth through Wnt/beta-catenin signaling. Toxicol Lett 229: 284-291.

38. Ducarouge B, Pelissier-Rota M, Laine M, Cristina N, Vachez Y, et al. (2013) CRF2 signaling is a novel regulator of cellular adhesion and migration in colorectal cancer cells. PLoS One 8: e79335.

39. Lambeth JD (2004) NOX enzymes and the biology of reactive oxygen. Nat Rev Immunol 4: 181-189.

40. Korswagen HC (2006) Regulation of the Wnt/beta-catenin pathway by redox signaling. Dev Cell 10: 687-688.

41. Zhang Z, Wang X, Cheng S, Sun L, Son YO, et al. (2011) Reactive oxygen species mediate arsenic induced cell transformation and tumorigenesis through Wnt/beta-catenin pathway in human colorectal adenocarcinoma DLD1 cells. Toxicol Appl Pharmacol 256: 114-121.

42. Son YO, Wang L, Poyil P, Budhraja A, Hitron JA, et al. (2012) Cadmium induces carcinogenesis in BEAS-2B cells through ROS-dependent activation of PI3 K/AKT/GSK-3beta/beta-catenin signaling. Toxicol Appl Pharmacol 264: $153-160$.

43. Kim MJ, Kim DH, Na HK, Surh YJ (2010) TNF-alpha induces expression of urokinase-type plasminogen activator and beta-catenin activation through generation of ROS in human breast epithelial cells. Biochem Pharmacol 80: 2092-2100.

44. Zhang DY, Pan Y, Zhang C, Yan BX, Yu SS, et al. (2013) Wnt/beta-catenin signaling induces the aging of mesenchymal stem cells through promoting the ROS production. Mol Cell Biochem 374: 13-20.

45. Dai RL, Zhu SY, Xia YP, Mao L, Mei YW, et al. (2011) Sonic hedgehog protects cortical neurons against oxidative stress. Neurochem Res 36: 67-75.

46. Song Y, Liang X, Hu Y, Wang Y, Yu H, et al. (2008) p,p'-DDE induces mitochondria-mediated apoptosis of cultured rat Sertoli cells. Toxicology 253: 53-61.

47. Frame S, Cohen P, Biondi RM (2001) A common phosphate binding site explains the unique substrate specificity of GSK3 and its inactivation by phosphorylation. Mol Cell 7: 1321-1327.
48. Yost C, Torres M, Miller JR, Huang E, Kimelman D, et al. (1996) The axisinducing activity, stability, and subcellular distribution of beta-catenin is regulated in Xenopus embryos by glycogen synthase kinase 3. Genes Dev 10: 1443-1454.

49. Varnat F, Duquet A, Malerba M, Zbinden M, Mas C, et al. (2009) Human colon cancer epithelial cells harbour active HEDGEHOG-GLI signalling that is essential for tumour growth, recurrence, metastasis and stem cell survival and expansion. EMBO Mol Med 1: 338-351.

50. Yoshikawa K, Shimada M, Mivamoto H, Higashijima J, Mivatani T, et al. (2009) Sonic hedgehog relates to colorectal carcinogenesis. J Gastroenterol 44: 1113-1117.

51. Wang H, Li YY, Wu YY, Nie YQ (2012) Expression and clinical significance of hedgehog signaling pathway related components in colorectal cancer. Asian Pac J Cancer Prev 13: 2319-2324.

52. Oniscu A, James RM, Morris RG, Bader S, Malcomson RDG, et al. (2004) Expression of Sonic hedgehog pathway genes is altered in colonic neoplasia. The Journal of Pathology 203: 909-917.

53. Agren M, Kogerman P, Kleman MI, Wessling M, Toftgard R (2004) Expression of the PTCH1 tumor suppressor gene is regulated by alternative promoters and a single functional Gli-binding site. Gene 330: 101-114

54. Song Y, Shi Y, Yu H, Hu Y, Wang Y, et al. (2011) p,p'-Dichlorodiphenoxydichloroethylene induced apoptosis of Sertoli cells through oxidative stressmediated p38 MAPK and mitochondrial pathway. Toxicol Lett 202: 55-60.

55. Shi YQ, Wang YP, Song Y, Li HW, Liu CJ, et al. (2010) p,p'-DDE induces testicular apoptosis in prepubertal rats via the Fas/FasL pathway. Toxicol Lett 193: 79-85.

56. Bedard K, Krause KH (2007) The NOX family of ROS-generating NADPH oxidases: physiology and pathophysiology. Physiol Rev 87: 245-313.

57. Coant N, Ben Mkaddem S, Pedruzzi E, Guichard C, Treton X, et al. (2010) NADPH oxidase 1 modulates WNT and NOTCH1 signaling to control the fate of proliferative progenitor cells in the colon. Mol Cell Biol 30: 2636-2650.

58. Juhasz A, Ge Y, Markel S, Chiu A, Matsumoto L, et al. (2009) Expression of NADPH oxidase homologues and accessory genes in human cancer cell lines, tumours and adjacent normal tissues. Free Radic Res 43: 523-532.

59. Gianni D, Taulet N, DerMardirossian C, Bokoch GM (2010) c-Src-mediated phosphorylation of NoxAl and Tks4 induces the reactive oxygen species (ROS)dependent formation of functional invadopodia in human colon cancer cells. Mol Biol Cell 21: 4287-4298.

60. Xia YP, Dai RL, Li YN, Mao L, Xue YM, et al. (2012) The protective effect of sonic hedgehog is mediated by the phosphoinositide3-kinase/AKT/Bcl-2 pathway in cultured rat astrocytes under oxidative stress. Neuroscience 209: $1-11$. 